\title{
Expression of the Early Growth Response 1 and 2 Zinc Finger Genes during Induction of Monocytic Differentiation
}

S. Kharbanda, T. Nakamura, R. Stone, R. Hass, S. Bernstein, R. Datta, V. P. Sukhatme, ${ }^{*}$ and D. Kufe Laboratory of Clinical Pharmacology, Dana-Farber Cancer Institute, Harvard Medical School, Boston, Massachusetts 02115, and ${ }^{*}$ Departments of Medicine, and Molecular Genetics and Cell Biology, Howard Hughes Medical Institute, University of Chicago, Chicago, Illinois 60637

\begin{abstract}
Members of the early growth response (EGR) gene family are rapidly induced after mitogenic stimulation of diverse cell types. The present work has examined EGR gene expression during differentiation of myeloid leukemia cells along the monocytic lineage and in activated monocytes. Low levels of EGR-1 transcripts were detectable in untreated U-937 and HL60 leukemia cells. In contrast, treatment of these cells with 12-0-tetradecanoylphorbol-13-acetate (TPA) was associated with increases (within $1 \mathrm{~h}$ ) in EGR-1 mRNA levels. The induction of monocytic differentiation by TPA and other agents was further associated with increases in EGR-2, but not EGR-3 or EGR-4, mRNA levels in these cells. Treatment of resting peripheral blood monocytes with the macrophage colony-stimulating factor (M-CSF) was also associated with rapid (within 15 min) increases in expression of the EGR-1 and EGR-2 genes. The results of nuclear run-on assays demonstrate that EGR-1 mRNA levels are increased in part by transcriptional activation of this gene in M-CSF-stimulated monocytes. The results also demonstrate that both EGR-1 and EGR-2 mRNA levels are regulated at the posttranscriptional level by a labile protein that destabilizes these transcripts. Finally, we demonstrate that dexamethasone, an inhibitor of monocytic differentiation, blocks the associated increases in EGR-1 and EGR-2 expression. Taken together, the results indicate that the EGR-1 and EGR-2 early response genes are involved in the induction of myeloid leukemia cell differentiation along the monocytic lineage and in the activation of human monocytes. (J. Clin. Invest. 1991. 88:571-577.) Key words: early response genes • macrophage colony-stimulating factor $\bullet$ monocyte $\bullet$ phorbol ester
\end{abstract}

\section{Introduction}

The treatment of human myeloid leukemia cell lines with certain agents, including 12-0-tetradecanoylphorbol-13-acetate (TPA), ${ }^{1}$ is associated with induction of monocytic differentia-

Address reprint requests to Dr. Kufe, Dana Farber Cancer Institute, Harvard Medical School, 44 Binney Street, Boston, MA 02115.

Received for publication 12 December 1990 and in revised form 11 April 1991.

1. Abbreviations used in this paper: EGR, early growth response; MCSF, macrophage colony-stimulating factor, PKC, protein kinase C; TNF, tumor necrosis factor; TPA, 12-0-tetradecanoylphorbol-13-acetate.

J. Clin. Invest.

(c) The American Society for Clinical Investigation, Inc.

0021-9738/91/08/0571/07 \$2.00

Volume 88, August 1991, 571-577 tion. The differentiated monocytic phenotype is characterized by growth inhibition, adherence, increase in monocyte surface members and induction of $\alpha$-naphthyl acetate esterase staining (1-4). Differentiation of myeloid leukemia cells along the monocytic lineage is also associated with a decrease in c-myc mRNA levels and induction of c-fms, macrophage colonystimulating factor (M-CSF), platelet-derived growth factor, and tumor necrosis factor (TNF) transcripts (5-8). Although multiple changes in gene expression thus occur during monocytic differentiation, the signaling pathways responsible for inducing these events remain unclear.

A variety of genes are rapidly and transiently activated when quiescent fibroblasts are stimulated with serum or growth factors. Many of these "immediate early response genes" code for transcription factors involved in nuclear signal transduction. One family of these genes which encodes nuclear proteins containing a leucine zipper DNA-binding motif includes the c-jun, jun-B, jun-D, c-fos, fos-B, and fra-1 genes (9). Another gene family coding for zinc finger transcription factors includes the early growth response (EGR) genes: EGR-1 (zif/ 268, NGF1-A, Krox 24, TIS-8), EGR-2 (Krox 20), EGR-3, and EGR-4 (10-16). Previous studies have demonstrated that the $\mathrm{c}$-jun, jun-B, and c-fos genes are activated during TPA-induced monocytic differentiation (7, 17-20). Moreover, the finding that pretreatment with dexamethasone inhibits expression of these genes, as well as TPA- or dimethyl sulfoxide (DMSO)-induced monocytic differentiation, has implicated a role for Jun/ AP-1 in this process (20-22). In contrast, little is known about the regulation of the EGR gene family in hematopoietic cell differentiation.

The EGR-1 gene encodes a 533-amino acid polypeptide with three tandem repeat units that conform to the consensus sequence for zinc binding (10). EGR-1 is induced during mitogenic stimulation of a variety of cell types including fibroblasts, epithelial cells, and B cells $(23,24)$. Other related genes (EGR2, EGR-3, EGR-4) have been identified with zinc fingers similar to those of EGR-1, but with dissimilarity elsewhere in the deduced amino acid sequence $(15,25$, and S. Patwardhan and V. P. Sukatme, unpublished data). The EGR-2 gene is also induced after growth stimulation of fibroblasts and lymphocytes (15), thus demonstrating that expression of these genes is not restricted to one cell type. Moreover, the EGR-3 gene is induced in human lymphocytes by phytohemagglutinin (S. Patwardhan and V. P. Sukhatme, unpublished data), whereas less is known about the expression of the EGR-4 gene.

The present studies have examined EGR gene expression during monocytic differentiation. The results demonstrate that the EGR-1 and EGR-2 genes are expressed during induction of human myeloid leukemia cells along this lineage. The results also demonstrate that these genes are expressed in human monocytes activated by M-CSF. 


\section{Methods}

Cell culture. U-937 and HL-60 cells were grown at a density of 1-2 $\times 10^{5} / \mathrm{ml}$ as previously described (18). Peripheral blood monocytes were isolated and cultured as described (26). Cells were treated with 32 nM TPA (Sigma Chemical Co., St. Louis, MO), $10 \mathrm{nM}$ bryostatin (provided by Dr. George Pettit, Arizona State University), $1.5 \%$ dimethylsulfoxide (DMSO; Fisher Chemical Co.), $1 \mu \mathrm{M}$ dexamethasone (Sigma Chemical Co.), $5 \mu \mathrm{g} / \mathrm{ml}$ actinomycin D (Sigma Chemical Co.) or $5 \mu \mathrm{g} / \mathrm{ml}$ cyclohexamide (Sigma Chemical Co.).

RNA isolation and Northern blot analysis. Total cellular RNA was isolated by a modification of the guanidine-isothiocyanate technique as described (18). The RNA $(20 \mu \mathrm{g})$ was analyzed by electrophoresis in $1 \%$ agarose-formaldehyde gels, transferred to nitrocellulose filters, and hybridized to the following ${ }^{32} \mathrm{P}$-labeled DNA probes: $(a)$ the $0.7-\mathrm{kb}$ non-zinc finger insert of a murine Egr-1 cDNA (10); $(b)$ the 0.6-kb non-zinc finger HindIII/EcoRI EGR-2 insert from clone p80 (15); (c) the 1.0-kb non-zinc finger EcoRI EGR-3 insert from clone Zap 4 (S. Patwardhan and V. P. Sukhatme, unpublished data); and $(d)$ the 0.6-kb non-zinc finger HindIII/EcoRI Egr-4 insert from clone 505 (S. Patwardhan and V. P. Sukhatme, unpublished data); and (e) the 2.0-kb PstI fragment of a chicken $\beta$-actin DNA purified from the pAl plasmid (27). Hybridizations were performed as described (18). Autoradiograms were scanned by means of a laser densitometer (Ultroscan XL, LKB Instruments, Inc., Gaithersburg, MD), and relative signal intensity was determined by means of the Gelscan HL software package (LKB Instruments, Inc.).

Nuclear run-on assays. Nuclei were isolated and newly elongated transcripts labeled with $\left[\alpha{ }^{32} \mathrm{P}\right] \mathrm{UTP}(800 \mathrm{Ci} / \mathrm{mmol}$, DuPont-New England Nuclear, Boston, MA) at $26^{\circ} \mathrm{C}$ for $30 \mathrm{~min}(18,26)$. The labeled RNA was hybridized to the following DNAs: (a) the 2.0-kb PstI fragment of the chicken $\beta$-actin pA1 plasmid (27); $(b)$ the $0.7-\mathrm{kb}$ HindIII/ EcoRI fragment of the murine Egr-1 cDNA (10); and (c) the 0.6-kb HindIII/EcoRI fragment of the EGR-2 cDNA (15). The digested DNAs were denatured by heating to $65^{\circ} \mathrm{C}$ for $15 \mathrm{~min}$, separated in $1 \%$ agarose gels, and transferred to nitrocellulose filters. The filters were prehybridized in $5 \times$ Denhardt's solution, $40 \%$ formamide, $4 \times$ SSC, 5 $\mathrm{nM} \mathrm{Na}{ }_{2}$ EDTA, $0.4 \%$ SDS, and $100 \mu \mathrm{g} / \mathrm{ml}$ yeast tRNA for $2 \mathrm{~h}$. Hybridizations were performed with $10^{7} \mathrm{cpm}$ of ${ }^{32} \mathrm{P}$-labeled RNA/ml hybridization buffer for $72 \mathrm{~h}$ at $42^{\circ} \mathrm{C}$. The filters were then washed in $2 \times$ $\mathrm{SSC} / 0.1 \%$ SDS at $37^{\circ} \mathrm{C}$ for $30 \mathrm{~min}, 200 \mathrm{ng} / \mathrm{ml} \mathrm{RNase} \mathrm{A}$ in $2 \times \mathrm{SSC}$ at $37^{\circ} \mathrm{C}$ for $20 \mathrm{~min}$, and $0.1 \times \mathrm{SSC} / 0.1 \% \mathrm{SDS}$ at $42^{\circ} \mathrm{C}$ for $30 \mathrm{~min}$.

\section{Results}

Expression of the EGR-1 gene was initially studied in U-937 myeloid leukemia cells. EGR-1 transcripts were at low to undetectable levels in untreated U-937 cells (Fig. $1 \mathrm{~A}$ ). In contrast, treatment of these cells with $32 \mathrm{nM}$ TPA was associated with the appearance of 3.4-kb EGR-1 transcripts at $1 \mathrm{~h}$ (Fig. $1 \mathrm{~A}$ ). Longer exposures to TPA resulted in down-regulation of EGR1 expression to undetectable levels at $24 \mathrm{~h}$ (Fig. $1 \mathrm{~A}$ ). The treatment of U-937 cells with TPA is associated with induction of monocytic differentiation (22). Moreover, recent studies have demonstrated that DMSO similarly induces these cells along the monocytic lineage (21). DMSO treatment also increased EGR-1 gene expression (Fig. 1 B). However, the DMSOtreated cells expressed both 3.4- and 1.8-kb EGR-1 mRNAs (Fig. 1 B). Furthermore, maximal levels of expression were achieved by $6 \mathrm{~h}$ and both transcripts remained detectable at 24 $\mathrm{h}$ of DMSO treatment (Fig. $1 B$ ).

Although the findings in U-937 cells suggested that EGR-1 expression is induced during monocytic differentiation, other studies were performed with the HL-60 leukemia cell line. Treatment of these cells with TPA is associated with induction of monocytic differentiation (1-4). Levels of the 3.4-kb EGR-1

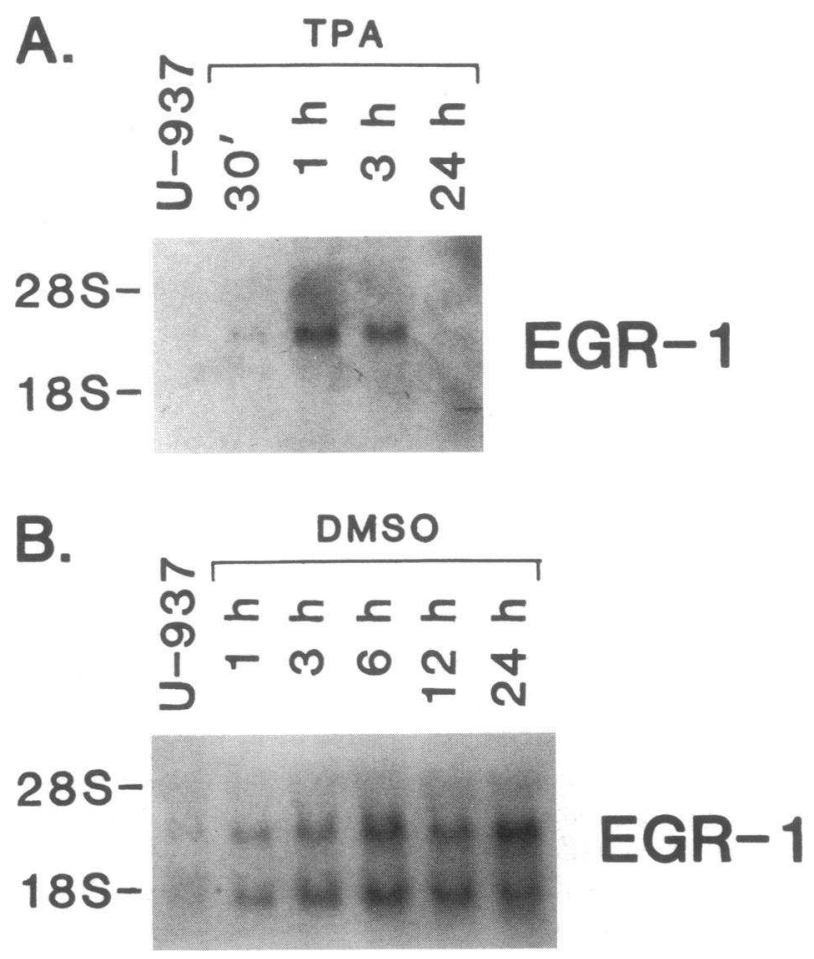

Figure 1. Effects of TPA and DMSO on EGR-1 mRNA levels in U-937 cells. U-937 cells were treated with $(A) 32 \mathrm{nM}$ TPA or $(B) 1.5 \%$ DMSO for the indicated times. Total cellular RNA $(20 \mu \mathrm{g})$ was isolated and hybridized to the ${ }^{32} \mathrm{P}$-labeled EGR-1 probe. Similar hybridizations to the labeled actin probe demonstrated equal loading of the lanes. Overexposure of the blot in $B$ demonstrated low levels of the 3.4- and 1.8-kb transcripts in uninduced U-937 cells.

transcripts were increased by $30 \mathrm{~min}$ of TPA exposure, subsequently declined, and then were increased again at $24 \mathrm{~h}$ (Fig. 2 $A)$. Similar findings were obtained with bryostatin 1, a structurally distinct agent that activates protein kinase $\mathrm{C}$ (PKC) and induces monocytic differentiation (28). However, whereas this agent also increased EGR-1 mRNA levels by $30 \mathrm{~min}$, maximal expression at $1 \mathrm{~h}$ was followed by down-regulation of these transcripts at $24 \mathrm{~h}$ (Fig. $2 \mathrm{~B}$ ). These findings indicated that EGR-1 gene expression is increased by a variety of different agents that act as inducers of monocytic differentiation.

Similar studies were performed to monitor expression of the EGR-2, EGR-3, and EGR-4 genes. There was no detectable expression of the EGR-2 gene in untreated U-937 cells. However, treatment with TPA was associated with increasing levels of the 3.4-kb EGR-2 transcripts at 3-24 h (Fig. $3 \mathrm{~A}$ ). Similar findings were obtained in TPA-induced HL-60 cells (Fig. $3 B$ ). Furthermore, treatment of HL-60 cells with bryostatin resulted in the appearance of EGR-2 transcripts at $1 \mathrm{~h}$ and progressive increases in expression of this gene through $24 \mathrm{~h}$ (Fig. $3 \mathrm{C}$ ). In contrast, there was no detectable induction of the EGR-3 or EGR-4 genes under these experimental conditions (data not shown). Taken together, these findings indicated that both EGR-1 and EGR-2 transcripts are increased during monocytic differentiation, although the kinetics of induction differ for the two genes.

Nuclear run-on assays were performed to determine whether EGR-1 and EGR-2 mRNA levels are regulated at the transcriptional level. EGR-1 gene transcription was detectable 


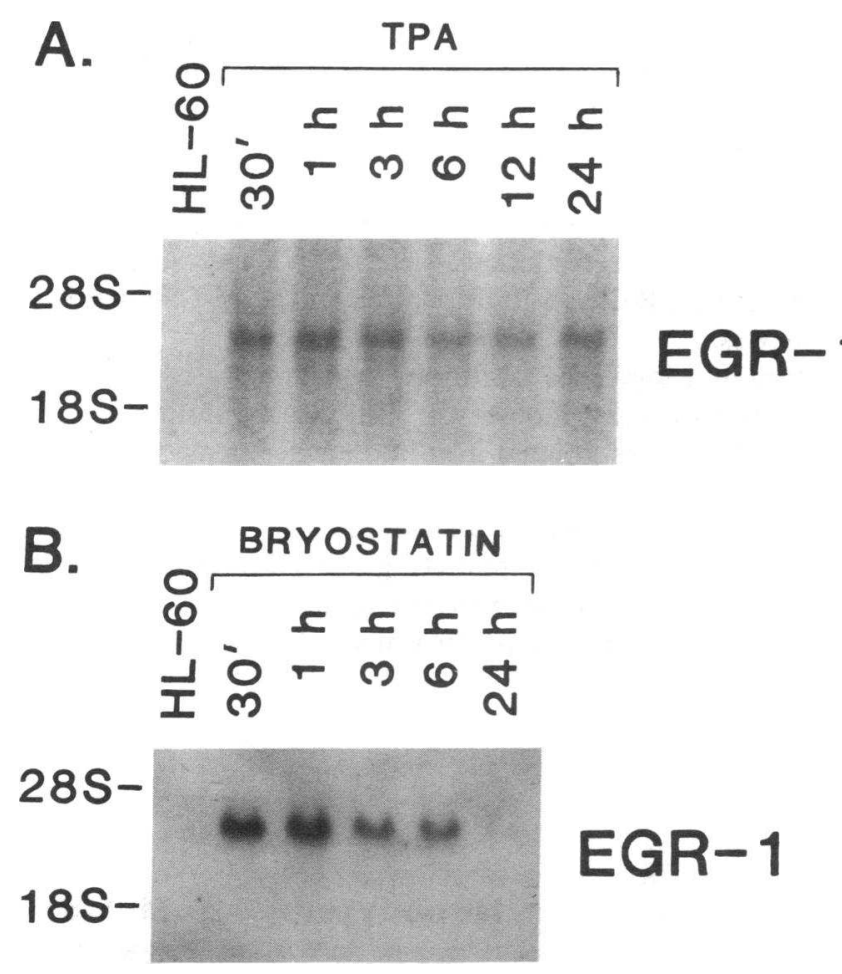

Figure 2. Effects of TPA and bryostatin on EGR-1 expression in HL60 cells. HL-60 cells were treated with $(A) 32 \mathrm{nM}$ TPA or $(B) 10 \mathrm{nM}$ bryostatin for the indicated times. Total cellular RNA $(20 \mu \mathrm{g})$ was hybridized to the ${ }^{32} \mathrm{P}$-labeled EGR-1 probe. Equal loading of the lanes was confirmed by hybridization to the actin probe.

in untreated U-937 cells and treatment with TPA for $1 \mathrm{~h}$ had little if any effect (Fig. 4). In contrast, as reported previously (29), TPA treatment was associated with detectable increases in transcription of the c-fos gene (Fig. 4). Other nuclear run-on studies were performed to monitor EGR-2 gene transcription. However, the rate of EGR-2 transcription in control and TPAtreated $(24 \mathrm{~h})$ cells was below the level of sensitivity for this assay. Thus, the available data indicate that increases in EGR-1 gene expression appear to be unrelated to activation at the transcriptional level.

The absence of TPA-induced transcriptional activation suggested that EGR-1 mRNA levels are regulated in part by a posttranscriptional mechanism. In order to study stability of the EGR-1 transcript, U-937 cells were treated with TPA for 1 $\mathrm{h}$ to induce EGR-1 expression and then exposed to actinomycin $\mathrm{D}$ for various times to inhibit further transcription. The half-life of EGR-1 mRNA as determined by densitometric scanning was $<10 \mathrm{~min}$ (Fig. $5 \mathrm{~A}$ ). In contrast, inhibition of protein synthesis with cycloheximide was associated with increases in EGR-1 mRNA levels and stabilization of this transcript $\left(t_{\frac{1}{2}}=36 \mathrm{~min} ;\right.$ Fig. $\left.5 \mathrm{~A}\right)$. Similar findings were obtained for EGR-2 mRNA levels. In U-937 cells treated with TPA for $24 \mathrm{~h}$, the half-lives of EGR-2 transcripts in the absence and presence of cycloheximide were $<10$ and $40 \mathrm{~min}$, respectively (Fig. $5 B$ ). These results indicated that the increases in EGR-1 and EGR-2 mRNA levels during TPA-induced monocytic differentiation are regulated by a labile protein involved in the degradation of these transcripts.

Although the findings with myeloid leukemia cell lines demonstrate that the EGR-1 and EGR-2 genes are induced during
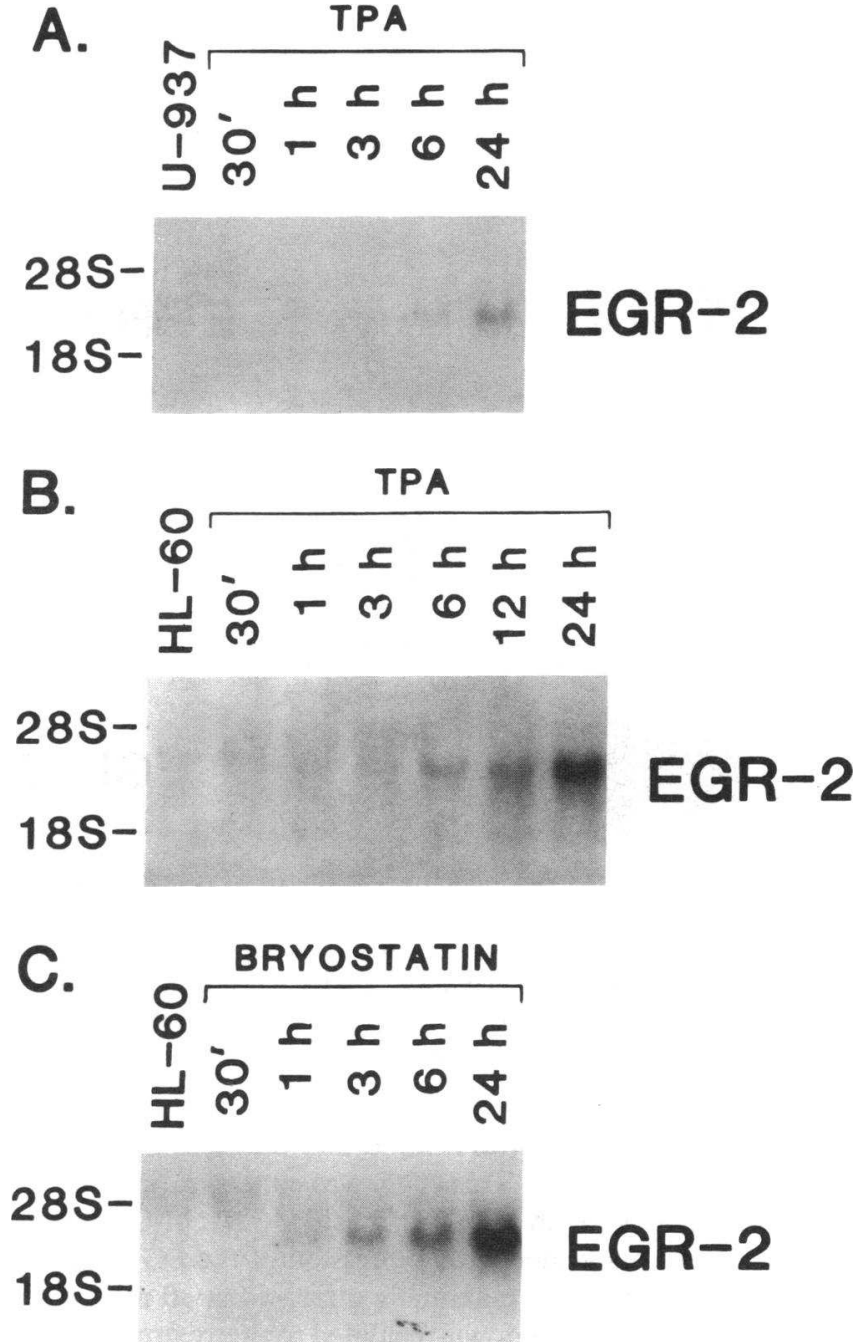

Figure 3. EGR-2 expression in U-937 and HL-60 cells. U-937 and HL-60 cells were treated with $32 \mathrm{nM}$ TPA or $10 \mathrm{nM}$ bryostatin for the indicated times. Total cellular RNA $(20 \mu \mathrm{g})$ was hybridized to the ${ }^{32}$ P-labeled EGR-2 probe.

induction of monocytic differentiation, other studies were performed with human peripheral blood monocytes. EGR-1 transcripts were at low to undetectable levels in resting monocytes (Fig. 6 A). However, treatment of these cells with $10^{3} \mathrm{U} / \mathrm{ml}$
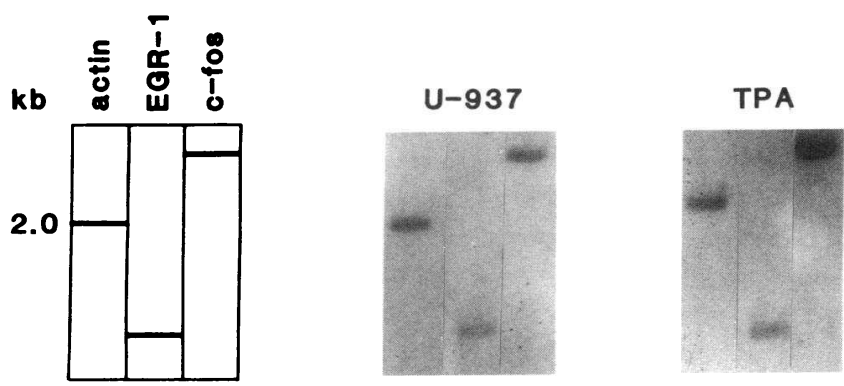

Figure 4. Effects of TPA on rates of EGR-1 gene transcription in U-937 cells. U-937 cells were treated with TPA for $1 \mathrm{~h}$. Nuclei were isolated and newly elongated ${ }^{32} \mathrm{P}$-labeled RNA transcripts were hybridized to $2 \mu \mathrm{g}$ of $\beta$-actin, EGR-1, or c-fos DNA inserts after restriction enzyme digestion and Southern blotting. The solid lines in the schematic represent the relative position of the DNA inserts. 

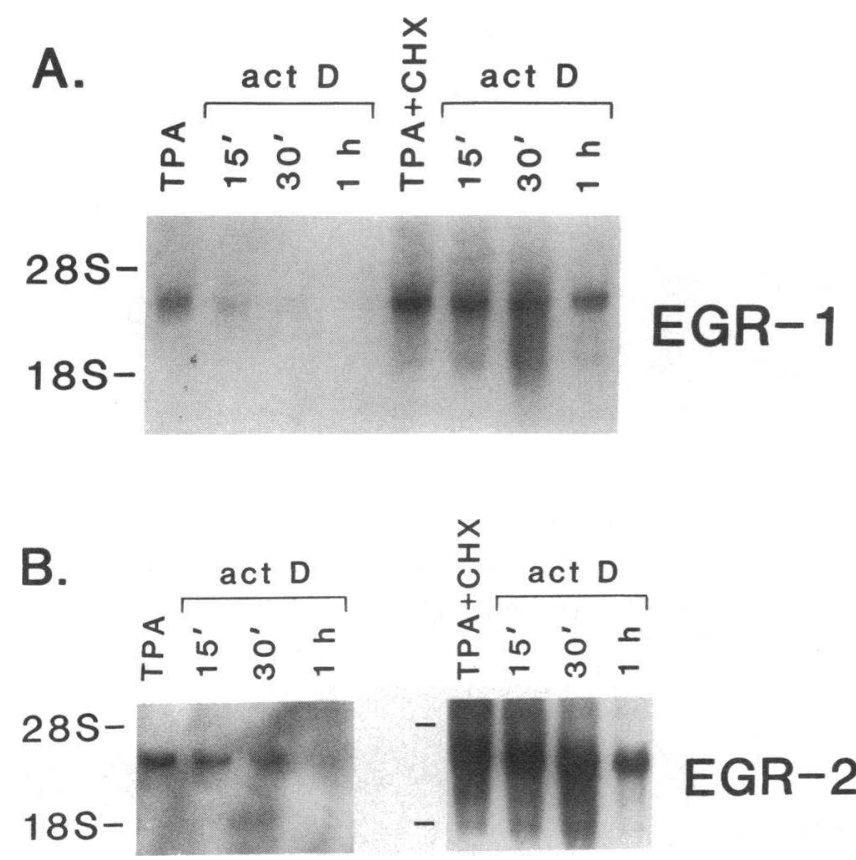

Figure 5. Effects of cycloheximide on stability of TPA-induced $(A)$ EGR-1 and $(B)$ EGR-2 transcripts. U-937 cells were treated with TPA alone or TPA/cycloheximide $(C H X)$ for $1 \mathrm{~h}$. Actinomycin D (Act D) was then added for the indicated times. Total cellular RNA $(20 \mu \mathrm{g})$ was hybridized to the ${ }^{32}$ P-labeled EGR-1 and EGR-2 probes. Hybridization to the actin probe demonstrated equal loading of the lanes.

M-CSF was associated with a rapid and transient increase in EGR-1 gene expression. This effect was concentration-dependent over a range of 10 to $10^{3} \mathrm{U} / \mathrm{ml}$ (Fig. $6 \mathrm{~A}$ ). M-CSF treatment was also associated with expression of the EGR-2 gene. EGR-2 transcripts were maximally increased at $30 \mathrm{~min}$ of $\mathrm{M}$ CSF exposure and then down-regulated to pretreatment levels

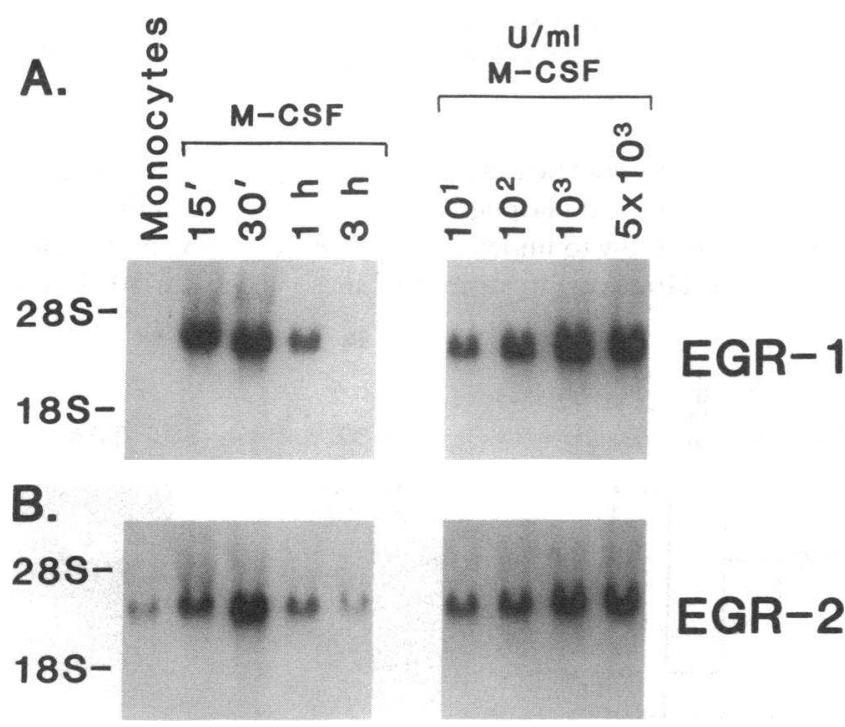

Figure 6. Effects of M-CSF on EGR-1 and EGR-2 mRNA levels in human monocytes. Resting peripheral blood monocytes were treated with $10^{3} \mathrm{U} / \mathrm{ml} \mathrm{M}-\mathrm{CSF}$ for the indicated times or with varying M-CSF concentrations for $15 \mathrm{~min}$. Total cellular RNA $(20 \mu \mathrm{g})$ was hybridized to the ${ }^{32}$ P-labeled $(A)$ EGR-1 and $(B)$ EGR-2 probes. Hybridization to the actin probe demonstrated equal loading of the lanes.

by $3 \mathrm{~h}$ (Fig. $6 \mathrm{~B}$ ). The increase in EGR-2 expression was also dependent on the M-CSF concentration (Fig. $6 \mathrm{~B}$ ). Boiling the M-CSF $\left(10^{3} \mathrm{U} / \mathrm{ml}\right)$ for $30 \mathrm{~min}$ completely abrograted the effects of this agent on expression of both the EGR-1 and EGR-2 genes (data not shown). These findings indicated that the activation of monocytes with M-CSF is associated with EGR-1 and EGR-2 expression. In contrast, there was no detectable induction of the EGR-3 and EGR-4 genes in the M-CSF-treated monocytes.

Run-on assays were performed to determine whether MCSF induces transcription of the EGR-1 gene in monocytes. Nuclear RNA was isolated from monocytes treated with $10^{3}$ $\mathrm{U} / \mathrm{ml} \mathrm{M-CSF}$ for $15 \mathrm{~min}$. The actin gene was constitutively active in resting monocytes and M-CSF had no detectable effect on this rate of transcription (Fig. $7 \mathrm{~A}$ ). Detectable levels of EGR-1 gene transcription were also found in untreated monocytes (Fig. $7 \mathrm{~A}$ ). In contrast, treatment of these cells with M-

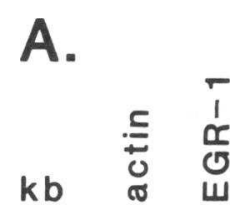

2.0

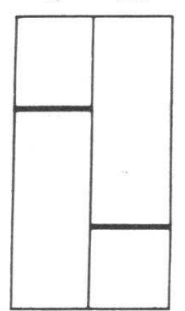

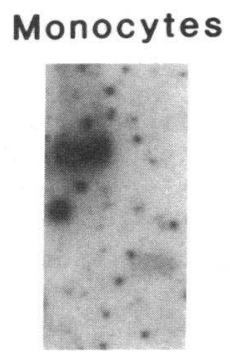

B.

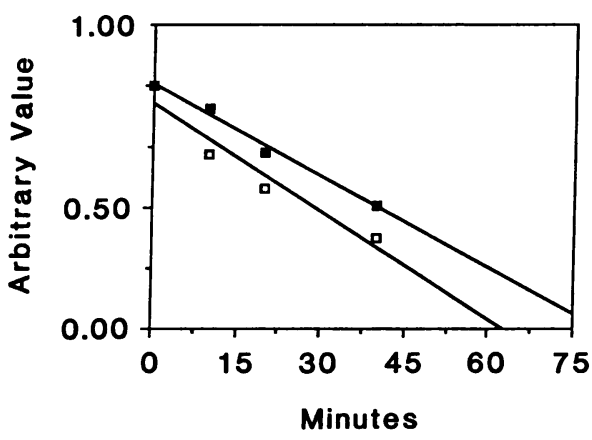

Figure 7. Regulation of EGR-1 mRNA levels in M-CSF-treated monocytes. $(A)$ Resting monocytes were treated with $10^{3} \mathrm{U} / \mathrm{ml} \mathrm{M}$ CSF for $15 \mathrm{~min}$. The nuclei were isolated and ${ }^{32} \mathrm{P}$-labeled transcripts hybridized to $2 \mu \mathrm{g}$ of actin or EGR-1 insert. As compared to the actin gene, EGR-1 gene transcription was increased 4.5-fold after M-CSF stimulation. Similar findings were obtained in two separate experiments. The solid lines in the schematic represent positions of the DNA insert. (B) Resting monocytes were treated with $10^{3} \mathrm{U} / \mathrm{ml} \mathrm{M}-$ CSF for 15 min and then actinomycin D. Cells were harvested at the indicated times and total cellular RNA $(20 \mu \mathrm{g})$ was hybridized to ${ }^{32} \mathrm{P}$ labeled EGR and actin probes. Intensity of the EGR-1 and EGR-2 signals was determined by laser densitometry and normalized to that for the level of actin hybridization. The half-lives for both EGR-1 and EGR-2 transcripts in resting monocytes were less than $10 \mathrm{~min}$ (data not shown). In M-CSF-treated monocytes, the half-lives for ( $\square$ ) EGR-1 and (ם) EGR-2 were 32 and 38 min, respectively. 
CSF was associated with approximately a four- to fivefold increase in EGR-1 transcription (Fig. $7 \mathrm{~A}$ ). We also compared the stability of the EGR-1 transcript in resting and M-CSF-treated monocytes by inhibiting transcription with actinomycin $D$. The half-life of EGR-1 mRNA in resting monocytes was $<10$ min, whereas M-CSF treatment was associated with a prolongation of the half-life to $32 \mathrm{~min}$ (Fig. $7 \mathrm{~B}$ ). Similar findings were obtained for EGR-2. Although the rate of EGR-2 transcription was below that detected in our run-on assays, stability studies demonstrated that the half-lives of EGR-2 transcripts in resting and M-CSF-treated monocytes were $<10$ and $38 \mathrm{~min}$, respectively (Fig. 7 B). Taken together, these results indicated that M-CSF regulates EGR-1 gene expression in monocytes by both transcriptional and posttranscriptional mechanisms, whereas EGR-2 expression is regulated at least in part by a posttranscriptional mechanism in these cells.

We have previously demonstrated that glucocorticoids inhibit induction of monocytic differentiation (20-22). Consequently, we treated TPA-induced U-937 cells with dexamethasone to determine the effects of this agent on EGR-1 gene expression. Although dexamethasone had no independent effect on EGR-1 mRNA levels in U-937 cells, this glucocorticoid blocked TPA-induced EGR-1 expression (Fig. $8 A$ ). Dexamethasone also inhibited the increases in EGR-1 mRNA levels associated with M-CSF treatment of resting monocytes (Fig. $8 \mathrm{~A}$ ). Similar results were obtained in studies monitoring the effects of dexamethasone on EGR-2 expression in U-937 and monocytes (Fig. $8 \mathrm{~B}$ ).

\section{Discussion}

The immediate-early response genes are induced in the absence of de novo protein synthesis by diverse mitogenic signals. An

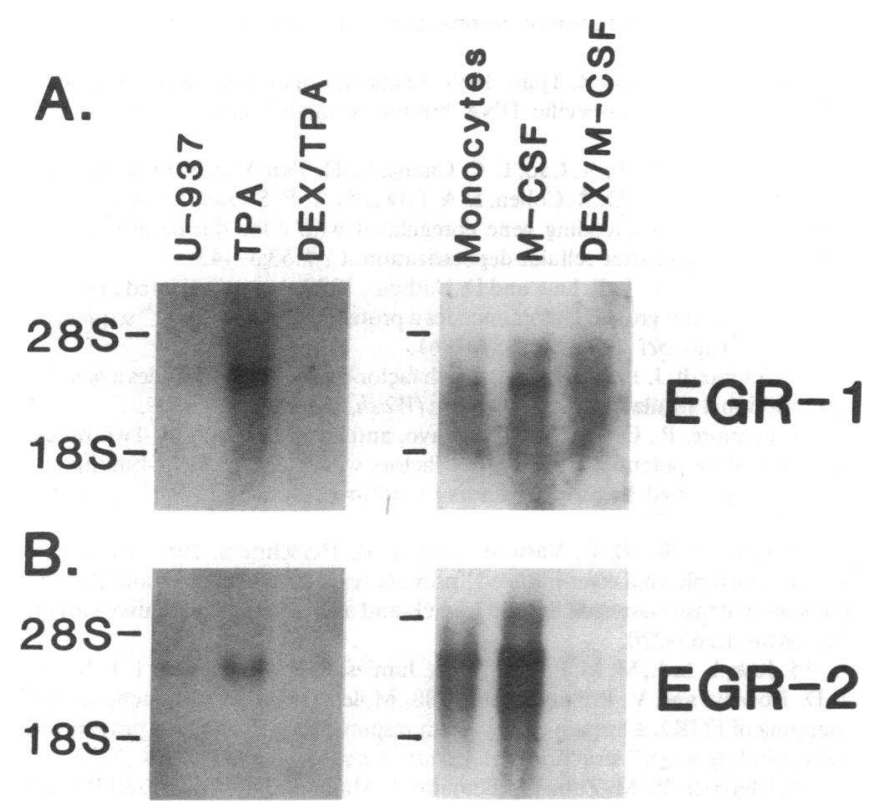

Figure 8. Effects of dexamethasone on EGR-1 and EGR-2 expression. U-937 cells were treated with TPA for $1 \mathrm{~h}$ or with $1 \mu \mathrm{M}$ dexamethasone $(D E X)$ for $12 \mathrm{~h}$ and then TPA for $1 \mathrm{~h}$. Resting peripheral blood monocytes were treated with $10^{3} \mathrm{U} / \mathrm{ml} \mathrm{M-CSF}$ for $15 \mathrm{~min}$ or with $1 \mu \mathrm{M}$ dexamethasone for $12 \mathrm{~h}$ and then M-CSF for $15 \mathrm{~min}$. Total cellular RNA $(20 \mu \mathrm{g})$ was hybridized to the $(A)$ EGR-1 and $(B)$ EGR-2 probes. important subset of these genes codes for transcription factors. These include: $(a)$ the c-fos, c-jun, and closely related leucine zipper genes; $(b)$ a member of the steroid and thyroid hormone receptor family $(29,30)$; and $(c)$ members of the EGR family. Previous studies have demonstrated that, in addition to proliferation, the c-fos gene is activated during differentiation of cells induced along the monocytic lineage $(7,17)$. Other work has shown that the c-jun gene is also induced during monocytic differentiation (18). Taken together with the finding that ectopic expression of c-jun induces differentiation of P19 embryonal carcinoma cells (31), these results have suggested that Jun/AP-1 plays a role in regulating gene expression during differentiation. Thus, certain immediate-early response genes appear to function in events other than growth control. In this context, whereas the EGR-1 gene is induced by growth signals, recent studies have demonstrated increased EGR-1 mRNA levels during neural and cardiac cell differentiation $(10,32)$.

The present results demonstrate that the EGR-1 gene is also expressed during induction of monocytic differentiation. These findings were obtained in myeloid leukemia cell lines induced with a variety of agents. Low levels of 3.4- and 1.8-kb EGR-1 transcripts were detectable in uninduced U-937 cells. We have previously shown that these two mRNAs are coexpressed in BALB/c 3T3 fibroblasts (33). However, treatment of U-937 cells with TPA or bryostatin was associated with increases in the only 3.4-kb EGR-1 transcript. Treatment of HL60 cells with these agents also resulted in increased expression of the larger transcript. These findings indicated that expression of the 3.4-kb EGR-1 mRNA is regulated by a PKC-dependent signaling mechanism. In contrast, treatment of U-937 cells with DMSO, an agent not known to activate PKC, increased expression of both the 3.4- and 1.8-kb transcripts. Although the basis for these patterns of EGR-1 expression is unclear, the activation of distinct signaling pathways may differentially regulate this gene by alternate splicing mechanisms. Taken together, these findings indicate that EGR-1 expression is increased by different classes of agents that induce the monocytic phenotype.

The treatment of resting human monocytes with M-CSF also resulted in induction of EGR-1 transcripts. This effect was associated with the acquisition of a more differentiated monocytic phenotype as characterized by the rapid (within $30 \mathrm{~min}$ ) induction of TNF gene expression (data not shown). TNF functions as a mediator of monocyte cytotoxicity and is induced by a variety of agents that activate these cells, including $\gamma$-interferon, endotoxin, and M-CSF (34-36). The mechanisms responsible for induction of the TNF gene in M-CSFtreated monocytes are unknown. However, of potential relevance to the present studies is the presence of an EGR-1 protein binding site (GCGGGGGCG) at positions -171 to -163 in the TNF gene promoter (M. Mohri and D. Kufe, unpublished data). Whereas nuclear run-on assays demonstrated transcriptional induction of the EGR-1 gene in activated monocytes, and not in TPA-treated myeloid leukemia cells, mRNA stability studies indicated regulation by a posttranscriptional mechanism in both cell types. The findings that a labile protein is involved in turnover of EGR-1 mRNA during monocytic differentiation is in concert with the presence of two AU-rich regions in the $3^{\prime}$ untranslated region of this transcript which may mediate selective mRNA degradation (37).

The present results similarly demonstrate increases in expression of the EGR-2 gene in myeloid leukemia cells induced 
along the monocytic lineage. However, the time course of EGR-2 expression in these cells was delayed compared to that for the EGR-1 gene. While these findings indicate distinct mechanisms of regulation, our studies in M-CSF-activated monocytes demonstrated similar kinetics of EGR-1 and EGR2 expression. Previous studies have demonstrated that the EGR-1 and EGR-2 genes are coregulated in response to mitogenic signals through stimulation of $\mathrm{CC}(\mathrm{A} / \mathrm{T})_{6} \mathrm{GG}$ elements in their promoters $(15,25)$. Although our nuclear run-on assays were unable to detect rates of EGR-2 transcription for comparison with EGR-1, the present findings demonstrate that EGR-2, like EGR-1, gene expression is regulated by a posttranscriptional mechanism during monocytic differentiation. The EGR-2 transcript also contains AU-rich sequences in the $3^{\prime}$ region and was stabilized by treatment with cycloheximide. Although there are thus certain similarities between the regulation of these genes during differentiation, the different kinetics during induction of myeloid leukemia cells by TPA suggest that other distinct mechanisms of regulation may occur at the transcriptional level. Indeed, induction of PC12 pheochromocytoma cell differentiation with nerve growth factor is associated with EGR-1, but not EGR-2, gene expression (15). Moreover, the absence of detectable changes in EGR-3 and EGR-4 expression in the present studies further indicates that members of the EGR gene family coinduced during mitogenic stimulation are regulated by distinct mechanisms during monocytic differentiation.

We have previously demonstrated that the EGR-1 gene maps to chromosome 5(5q23-31)(10). Deletions involving the long arm of chromosome 5 , particularly $5 \mathrm{q} 31$, are detectable in nearly half of patients with therapy-related acute myelogenous leukemia (38). Moreover, $5 \mathrm{q}^{-}$is found in $>70 \%$ of patients with certain types of myelodysplasia, particularly refractory anemia with excess blasts (38). Of interest, while genes for a number of growth factors and receptors are clustered near this region, EGR-1 and the glucocorticoid receptor are the only known genes coding for proteins with transcriptional regulatory activity. A decrease in EGR-1 expression by allelic deletion could contribute to loss of growth control or the ability of myeloid cells to undergo differentiation. The up-regulation of EGR-1 expression during induction of monocytic differentiation would support this hypothesis. Of interest, EGR-1 shares homology with the Wilms' tumor susceptibility gene which also codes for a zinc finger DNA binding protein (39). In contrast, the EGR-2 gene has been mapped to a region (10q21-22) not recognized for structural rearrangements in myeloid leukemias (15).

Finally, we have recently demonstrated that dexamethasone inhibits activation of c-jun transcription during induction of monocytic differentiation (40). Studies in other cells have shown that the activated glucocorticoid receptor binds to Jun/ AP-1 and interferes with activation of the TPA-responsive element (41-43). Dexamethasone may therefore block c-jun expression during monocytic differentiation by inhibiting autoregulation of c-jun transcription. The present studies demonstrate that dexamethasone similarly inhibits EGR-1 and EGR-2 gene expression in both TPA-treated myeloid leukemia cells and activated monocytes. The basis for this effect remains unclear. Nonetheless, the inhibition of both c-jun and EGR expression by dexamethasone may prevent the coupling of early biochemical signaling events to long-term changes in gene expression. Indeed, this glucocorticoid inhibits appear- ance of the monocytic phenotype, including the induction of TNF and c-fms expression (20-22).

\section{Acknowledgments}

This investigation was supported by U. S. Public Health Service Grants CA-42802 and CA-34183 awarded by the National Cancer Institute, Department of Health and Human Services, by a postdoctoral fellowship from the Deutsche Forschungsgemeinschaft (Dr. Hass), and by a Burroughs Wellcome Clinical Pharmacology Scholar Award (Dr. Kufe).

\section{References}

1. Huberman, E., and M. P. Callahan. 1979. Induction of terminal differentiation of human promyelocytic leukemic cells by tumor-producing agents. Proc. Natl. Acad. Sci. USA. 76:1293-1297.

2. Lotem, H., and L. Sachs. 1979. Regulation of normal differentiation in mouse and human myeloid leukemic cells by phorbol esters and the mechanism of tumor production. Proc. Natl. Acad. Sci. USA. 76:5158-5162.

3. Rovera, G., T. A. O'Breine, and L. Diamond. 1979. Induction of differentiation in human promyelocytic leukemia cells by tumor promoters. Science (Wash. DC). 204:868-870.

4. Rovera, G., D. Ferraro, G. L. Pagliardi, J. Vartikar, S. Pessano, L. Bottera, S. Abraham, and D. Lebman. 1982. Induction of differentiation of human myeloid leukemias by phorbol esters: phenotypic changes and mode of action. Ann. N.Y. Acad. Sci. 397:211-220.

5. Horiguchi, J., M. Warren, P. Ralph, and D. Kufe. 1986. Expression of the macrophage specific colony-stimulating factor (CSF-1) during human monocytic differentiation. Biochem. Biophys. Res. Commun. 141:924-930.

6. Pantazis, P., E. Sariban, D. Kufe, and H. Antoniades. 1986. Induction of c-sis gene expression and synthesis of platelet-derived growth factor during human monocytic differentiation. Proc. Natl. Acad. Sci. USA. 83:6455-6459.

7. Sariban, E., T. Mitchell, and D. W. Kufe. 1985. Expression of the c-fms proto-oncogene during human monocytic differentiation. Nature (Lond.). 316:64-66.

8. Wang, A. M., A. A. Creasey, M. B. Ladner, L. S. Lin, J. Strickler, J. N. Van Arsdell, R. Yamamoto, and D. F. Mark. 1985. Molecular cloning of the complementary DNA for human tumor necrosis factor. Science (Wash. DC.). 228:149154.

9. Mitchell, P. J., and R. Tjian. 1989. Transcriptional regulation in mammalian cells by sequence-specific DNA binding protein. Science (Wash. DC.). 242:371-378.

10. Sukhatme, V. P., X. Cao, L. C. Chang, C.-H. Tsai-Morris, D. Stamenkovich, P. C. P. Ferreira, D. R. Cohen, S. A. Edwards, T. B. Shows, T. Curran, et al. 1988. A zinc-finger encoding gene coregulated with c-fos during growth and differentiation, and after cellular depolarization. Cell. 53:37-43.

11. Christy, B. A., L. F. Lau, and D. Nathans. 1988. A gene activated in mouse 3 T 3 cells by serum growth factors encodes a protein with "zinc finger" sequences. Proc. Natl. Acad. Sci. USA. 85:7857-7861.

12. Milbrandt, J. 1987. A nerve growth factor-induced gene encodes a possible transcriptional regulatory factor. Science (Wash. DC.). 238:797-799.

13. Lemaire, P., O. Revelant, R. Bravo, and P. Charney. 1988. Two mouse genes encoding potential transcription factors with identical DNA-binding domains are activated by growth factors in cultured cells. Proc. Natl. Acad. Sci. USA. 85:4691-4695.

14. Lim, R. W., B. C. Varnum, and H. R. Herschman. 1987. Cloning of tetradecanoyl phorbol ester-induced "primary response" sequences and their expression in density-arrested Swiss 3T3 cells and a TPA non-proliferative variant. Oncogene. 1:263-270.

15. Joseph, L. J., M. M. LeBeau, G. A. Jamieson, Jr., S. Acharya, T. B. Shows, J. D. Rowley, and V. P. Sukhatme. 1988. Molecular cloning, sequencing, and mapping of EGR2, a human early growth response gene encoding a protein with "zinc binding finger" structure. Proc. Natl. Acad. Sci. USA. 85:7164-7168.

16. Chavrier, P., M. Zerial, P. Lemaire, J. Almendral, R. Bravo, and P. Charney. 1988. A gene encoding a protein with zinc fingers is activated during $G_{0} / G_{1}$ transition in cultured cells. EMBO (Eur. Mol. Biol. Organ.) J. 7:29-36.

17. Mitchell, R. L., C. Henning-Chubb, E. Huberman, and I. M. Verma. 1986. c-fos expression is neither sufficient nor obligatory for differentiation of monomyelocytes to macrophages. Cell. 45:497-504.

18. Sherman, M. L., R. M. Stone, R. Datta, S. H. Bernstein, and D. W. Kufe. 1990. Transcriptional and post-transcriptional regulation of c-jun expression during monocytic differentiation of human myeloid leukemic cells. J. Biol. Chem. 265:3320-3323. 
19. Datta, R., M. L. Sherman, R. M. Stone, and D. Kufe. 1991. Expression of the jun-B gene during induction of monocytic differentiation. Cell Growth Differ. 2:43-49.

20. Horiguchi, J., D. Spriggs, K. Imamura, R. Stone, R. Luebbers, and D. Kufe. 1989. Role of arachidonic acid metabolism in the transcriptional induction of tumor necrosis factor gene expression by phorbol ester. Mol. Cell. Biol. 9:252258.

21. Nakamura, T., S. Kharbanda, D. Spriggs, and D. Kufe. 1990. Effects of dexamethasone on induction of monocytic differentiation in human U937 cells by dimethyl sulfoxide. J. Cell. Physiol. 142:261-267.

22. Stone, R., K. Imamura, M. Sherman, and D. Kufe. 1990. Inhibition of phorbol ester-induced monocytic differentiation and c-fms expression by dexamethasone: potential involvement of arachidonic acid metabolites. Blood. 76:1225-1232.

23. Sukhatme, V. P. 1990 . Early transcriptional events in cell growth: the EGR family. J. Am. Soc. Nephrol. 1:859-866.

24. Seyfert, V. L., V. P. Sukhatme, and J. G. Munroe. 1989. Differential expression of a zinc finger-encoding gene in response to positive versus negative signaling through receptor immunoglobulin in murine B lymphocytes. Mol. Cell. Biol. 9:2083-2088.

25. Rangnekar, V. M., A. C. Aplin, and V. P. Sukhatme. 1990. The serum and TPA responsive promoter and intron-exon structure of EGR2, a human early growth response gene encoding a zinc finger protein. Nucleic Acids. Res. 18:2749-2757

26. Sariban, E., R. Luebbers, and D. Kufe. 1988. Transcriptional and posttranscriptional control of $\mathrm{c}$-fos gene expression in human monocytes. Mol. Cell. Biol. 8:340-346.

27. Cleveland, D. W., M. A. Lopata, R. J. MacDonald, N. J. Cowan, J. W. Rutter, and M. W. Kirschner. 1980. Number and evolutionary conservation of alpha- and beta-tubulin and cytoplasmic beta and gamma-actin genes using specific clones cDNA probes. Cell. 20:95-105.

28. Stone, R. M., E. Sariban, G. R. Pettit, and D. W. Kufe. 1988. Bryostatin activates protein kinase $\mathrm{C}$ and induces monocytic differentiation of HL-60 cells. Blood. 72:208-213.

29. Hazel, T. G., D. Nathans, and L. F. Lau. 1988. A gene inducible by serum growth factors encodes a member of the steroid and thyroid hormone superfamily. Proc. Natl. Acad. Sci. USA. 85:8444-8448.

30. Milbrandt, J. 1988. Nerve growth factor induces a gene homologous to the glucocorticoid receptor gene. Neuron. 1:183-188.

31. de Groot, R. P., F. A. E. Kruyt, P. T. van der Saag, and W. Kruijer. 1990 Ectopic expression of c-jun leads to differentiation of P19 embryonal carcinoma cells. EMBO (Eur. Mol. Biol. Organ.) J. 9:1831-1837.
32. Cao, X., R. A. Koski, A. Gashler, M. McKiernan, C. F. Morris, R. Gaffney, R. V. Hay, and V. P. Sukhatme. 1990. Identification and characterization of the Egr-1 gene product, a DNA-binding zinc finger protein induced by differentiation and growth signals. Mol. Cell. Biol. 10:1931-1939.

33. Sukhatme, V. P., S. Kartha, F. G. Toback, R. Taub, R. G. Hoover, and C.-H. Tsai-Morris. 1987. A novel early growth response gene rapidly induced by fibroblast, epithelial cell and lymphocyte mitogens. Oncogene Res. 1:343-355.

34. Warren, M. K., and P. Ralph. 1986. Macrophage growth factor CSF-1 stimulates human monocyte production of interferon, tumor necrosis factor, and colony stimulating activity. J. Immunol. 137:2281-2285.

35. Philip, R., and L. Epstein. 1986. Tumor necrosis factor as immunomodulator and mediator of monocyte cytotoxicity induced by itself, gamma-interferon and interleukin-1. Nature (Lond.). 323:86-89.

36. Kornbluth, R. S., and T. S. Edgington. 1986. Tumor necrosis factor production by human monocytes is a regulated event: induction of TNF-alpha mediated cellular cytotoxicity by endotoxin. J. Immunol. 137:2585-2591.

37. Shaw, G., and R. Kamen. 1986. A conserved AU sequence from the 3 untranslated region of GM-CSF mRNA mediates selective mRNA degradation. Cell. 46:659-667.

38. Le Beau, M. M., K. S. Albain, R. A. Larson, J. W. Vardiman, E. M. Davis, R. R. Blough, H. M. Golomb, and J. D. Rowley. 1986. Clinical and cytogenetic correlations in 63 patients with therapy-related myelodysplastic syndromes and acute nonlymphocytic leukemia: further evidence for characteristic abnormalities of chromosomes numbers 5 and 7. J. Clin. Oncol. 4:325-345.

39. Haber, D. A., A. J. Buckler, T. Glaser, K. M. Call, J. Pelletier, R. L. Sohn, E. C. Douglass, and D. E. Housman. 1990. An internal deletion within an 11 p13 zinc finger gene contributes to the development of Wilms' tumor. Cell. 61:12571269.

40. Hass, R., M. Brach, S. Kharbanda, G. Giese, P. Traub, and D. Kufe. 1991 Dexamethasone inhibits phorbol ester-induced monocytic differentiation by down-regulation of c-fos and c-jun (AP-1).J. Cell. Physiol. In press.

41. Jonat, C., H. J. Rahmsdorf, K-K. Park, A. C. B. Cato, S. Gebel, H. Ponta, and $P$. Herrlich. 1990. Antitumor promotion and antiinflammation: down-modulation of AP-1 (Fos/Jun) activity by glucocorticoid hormone. Cell. 62:11891204.

42. Yang-Yen, H-F., J-C. Chambard, Y-L. Sun, T. Smeal, T. J. Schmidt, J. Drouin, and M. Karin. 1990. Transcriptional interference between c-jun and the glucocorticoid receptor: mutual inhibition of DNA binding due to direct proteinprotein interaction. Cell. 62:1205-1215.

43. Schule, R., P. Rangarajan, S. Kliewer, L. J. Ransone, J. Bolado, N. Yang I. M. Verma, and R. M. Evans. 1990. Functional antagonism between oncoprotein c-jun and the glucocorticoid receptor. Cell. 62:1217-1226. 